\title{
Dividend Smoothing And The Long-Run Stability Between Dividends And Earnings In Korea
}

\author{
Jin-Ho Jeong, Korea University, Korea
}

\begin{abstract}
There have been no empirical attempts to estimate and verify the dividend-earnings relation reflecting both the signaling and dividend smoothing hypotheses. This study proposed a cointegration model to test both hypotheses in an integrated framework in order to provide better insight into the dividend and earning relation. We are particularly interested in the issue of whether the model can detect a presence of inter-temporal relations between dividends and earnings. The implications of the signaling model and smoothing model of dividends were empirically tested using the recent 26 annual series data of dividends and earnings up to year 2006 for 226 firms listed on the Korea Stock Exchange. The results of t-test and logistic regression show that the presence of cointegration is positively related to the degree of information asymmetry, a result consistent with the dividend signaling hypothesis. In addition, dividend smoothing is identified as an underlying force to make dividends and earnings cointegrated.
\end{abstract}

Keywords: Dividend Policy, Dividend Smoothing, Dividend Signaling, Cointegration

\section{INTRODUCTION}

$\varnothing^{2}$ $\mathrm{n}$ the signaling model of dividend, a firm's dividend policy is hypothesized to convey the information about its future prospects that is privately observed only by insiders. John and Williams (1985) have demonstrated how dividends can act as a credible signal of the fundamental earnings prospects of the firm. In practice, for dividends to be a credible signal, insider should maintain a systematic relationship between expected earnings and dividends. In this regard, Lintner (1956) found that managers smoothly adjust firms' dividends with respect to earnings and maintain a long-run target payout ratio. Lintner's further investigations show that most firms follow a partial adaptation process making a gradual dividend adjustment to the target ratio if current payout is deviated from the target ratio. Both the dividend smoothing and the dividend signaling hypotheses have been confirmed by a number of subsequent studies. Whereas dividend smoothing and dividend signaling are well-established empirical facts, the empirical evidences are based principally on information collected in the US market. The dividend policies of corporations differ significantly across countries due to a variety of institutional and financial market differences. ${ }^{1}$ The principal objective of this study is to assess the dividend policies of firms in Korea. In particular, this study investigates whether Korean firms follow dividend policies as in developed markets in which dividend smoothing and dividend signaling become stylized facts.

A common problem for the researchers studying the dividend signaling hypothesis and the dividend smoothing hypothesis is that most of the studies tend to focus on the signaling model of dividend (e.g. dividend announcement studies) or the smoothing model of dividend separately (e.g. partial adjustment models), but not both. There have been no empirical attempts to estimate and verify the dividend-earnings relation reflecting both hypotheses. Existing empirical tests cannot really identify the types of mechanisms for the dividend-earnings relation (e.g. the joint considerations of signaling and dividend smoothing). In this study, I propose a cointegration

1 Aivazian et al (2003) find that empirical dividend policy equations of emerging market firms are structurally different from those of US firms. 
model to test both hypotheses in an integrated framework in order to provide better insight into the dividend and earning relation. This allows us to investigate not only the informational content of dividend but also the underlying factor to make dividend signal to be credible.

The objective of this paper is two fold. First, we test the informational content of dividend. For this purpose, I construct a model to show the predictive relations among dividends and future earnings at the firm level. This paper is particularly interested in the issue of whether the model can detect a presence of inter-temporal relations between dividends and earnings. Second, I test the dividend smoothing hypothesis using a non-linear framework involving dividends and earnings stream. Tests of the time-series implications of dividend models in a cointegrating framework offer a distinctive approach to examine the ability of each hypothesis to explain corporate dividend behavior and hence, identify the types of mechanisms for the dividend-earnings relation. The most significant use of the cointegration model is that this model is able to identify the long-term equilibrium relationship between dividends and earnings. Because theoretical analysis specifies the long-run equilibrium relationship between the earnings and dividend time series in the presence of information asymmetry, the cointegration model employed in this study is regarded as a more direct test of the theoretical arguments in this area. Also a test is performed to examine the relationship between this derived dividend-setting behavior of a firm and the information environment using both multivariate and univariate techniques. The evidence shows that dividend-earnings relation depends on the degree of information asymmetry and dividend smoothing is an underlying factor to maintain a long-term equilibrium relationship between dividends and earnings. The remainder of this paper is organized as follows. Section II lays out the basic model. Section III describes the data and the methodology employed in this study. Section IV reports the empirical results. Section V summarizes and concludes the study and offers suggestions for future research.

\section{MODEL}

\section{Description Of Dividend Payout Pattern}

Assume that the dividend payout at time $\mathrm{t}$ can be described as follows.

$\operatorname{DPS}_{\mathrm{t}}=\mathrm{P}^{*}\left(\mathrm{E}\left[\mathrm{EPS}_{\mathrm{t}+1} \mid \mathrm{M}_{\mathrm{t}}, \mathrm{I}_{\mathrm{t}}\right]\right)^{ß}$

and $\mathrm{EPS}_{\mathrm{t}+1}=\mathrm{EPS}_{\mathrm{t}} \mathrm{Z}_{\mathrm{t}} \mathrm{V}_{\mathrm{t}+1}, \mathrm{Z}_{\mathrm{t}} \quad \varepsilon \mathrm{I}_{\mathrm{t}}$, and $\mathrm{EPS}_{\mathrm{t}} \varepsilon \mathrm{M}_{\mathrm{t}}$.

where DPS $_{t}$ is dividend per share, EPS $S_{t}$ is earning per share, $M_{t}$ is a public information set, $I_{t}$ is an insider's information set at time $t, E$ is the expectation operator, $Z_{t}$ is a signal of the firm's $t+1$ earnings observed at time $t$, $\mathrm{V}_{\mathrm{t}+1}$ is an innovation term with mean 1, which is independent of both public and private information at time $t$, and $\mathrm{P}$ can be interpreted as a dividend payout ratio when $\beta=1$. Equation (1) and (2) imply that dividends are based on the earnings observable only to insiders conditioned on the true quality of a firm. If a firm maintains a constant dividend payout ratio, then $\beta$ is equal to one. B less than one indicates that dividends are a concave function of expected future earnings conditioned on the insider's private information thereby implying dividend smoothing. ${ }^{2}$ Substituting (2) into (1) implies that

$\operatorname{DPS}_{\mathrm{t}}=\mathrm{P}^{*}\left(\mathrm{E}\left[\mathrm{EPS}_{\mathrm{t}} \mathrm{Z}_{\mathrm{t}} \mathrm{V}_{\mathrm{t}+1} \mid \mathrm{M}_{\mathrm{t}}, \mathrm{I}_{\mathrm{t}}\right]\right)^{\beta}$

\footnotetext{
2 This model is similar to that of the John and Williams (1985) in the sense that the unknown attribute is the expected earnings. Miller and Rock (1985) use the current earnings as the unknown attribute. However, the conflict between John and Williams (1985) and Miller and Rock is resolved in this paper. In terms of empirical setting, this study allows the dividend signal error for the current earnings (i.e., $\varepsilon$ in equation (5)), assuming that the current earnings are the biased estimator of the expected earnings (i.e., equation (2)). $\beta$ is used to consider the degree of dividend smoothing.
} 
Because $\mathrm{EPS}_{\mathrm{t}}$ and $\mathrm{Z}_{\mathrm{t}}$ are measurable with respect to management's time $t$ information which is the joint of the public information $\left(\mathrm{M}_{\mathrm{t}}\right)$ and their private signal $\left(\mathrm{Z}_{\mathrm{t}}\right)$,

$\mathrm{E}\left[\mathrm{EPS}_{\mathrm{t}} \mathrm{Z}_{\mathrm{t}} \mathrm{V}_{\mathrm{t}+1} \mid \mathrm{M}_{\mathrm{t}}, \mathrm{I}_{\mathrm{t}}\right]=\mathrm{EPS}_{\mathrm{t}} \mathrm{Z}_{\mathrm{t}} \mathrm{E}\left[\mathrm{V}_{\mathrm{t}+1} \mid \mathrm{M}_{\mathrm{t}}, \mathrm{I}_{\mathrm{t}}\right]$

Because the random innovation term is independent of $\mathrm{M}_{t}$ and $\mathrm{I}_{\mathrm{t}}$ and has mean $0, E\left[V_{t+1} \mid M_{t}, I_{t}\right]=1$. Hence we can express (3) as

$\operatorname{DPS}_{\mathrm{t}}=\mathrm{P}^{*}\left(\mathrm{EPS}_{\mathrm{t}} \mathrm{Z}_{\mathrm{t}}\right)^{\beta}$

The degree of smoothing can be measured by the curvature of equation (4). For a curve DPS $\mathrm{t}_{\mathrm{t}}=$ $\mathrm{P} *\left(\mathrm{EPS}_{\mathrm{t}} \mathrm{Z}_{\mathrm{t}}\right){ }^{\beta}$, the curvature is given by $(1-\beta) / \mathrm{EPS}_{\mathrm{t}} . \quad \beta$ can be estimated by taking the natural log of equation (4) to yield the following testable relationship

$\operatorname{lnDPS}_{\mathrm{t}}=\mathrm{a}+\beta \operatorname{lnEPS} \mathrm{t}_{\mathrm{t}}+\varepsilon_{\mathrm{t}}$

where $\varepsilon_{t}=\beta \ln \left(Z_{t}\right)$ and $a=\ln (P)$. Equation (5) will be used for finding the equilibrium relationship between dividends and earnings.

\section{Identification Of Equilibrium Relationship Between Earnings And Dividends - Cointegration}

According to the dividend signaling hypothesis, if dividends continue to separate from expected earnings in the long-run, then there will be a force which begins to bring them together again to maintain a long-term equilibrium relationship between dividends and earnings. The dividend smoothing hypothesis suggests that this underlying force is the manager's behavior to pay smoothed dividend with respect to earnings. In econometric sense, if there exists a long-term equilibrium relationship between dividends and earnings (in fact, an equilibrium relationship between natural log of dividends and natural log of earnings in equation (5)), then the deviations from this relationship, $\varepsilon_{t}$ in equation (5) will follow a stationary process even though dividends and earnings follow non-stationary process. The idea of finding the long-run equilibrium relationship was captured in cointegration developed by Engle and Granger (1987). Cointegration implies that deviations from equilibrium are stationary, with finite variance, even though the series themselves are nonstationary and have infinite variance. Engle and Granger show that the existence of a stationary process for the combination of variables in a system implies the presence of a long run equilibrium relationship among variables.

\section{Test Of Cointegration}

As a general rule, nonstationary time series variables should not be used in regression models, in order to avoid the problem of spurious regression. There is an exception to this rule. If $\operatorname{lnDPS}_{t}$ and $\operatorname{lnEPS}_{t}$ are nonstationary $\mathrm{I}(1)$ variables, then we would expect that their difference, or any linear combination of them, such as $\varepsilon_{t}=\operatorname{lnDPS}_{t}-a-\beta \operatorname{lnEPS} S_{t}$, to be $\mathrm{I}(1)$ as well. However there are important cases when $\varepsilon_{t}=\operatorname{lnDPS}_{t}-a-\beta \operatorname{lnEPS} S_{t}$ is a stationary $\mathrm{I}(0)$ process. In this case $\operatorname{lnDPS}_{\mathrm{t}}$ and $\operatorname{lnEPS}_{\mathrm{t}}$ are said to be cointegrated. Cointegration implies that $\operatorname{lnDPS}_{\mathrm{t}}$ and $\operatorname{lnEPS}_{\mathrm{t}}$ share similar stochastic trends, and they never diverge too far from each other since their difference $\varepsilon_{t}$ is stationary,. The cointegrated variables $\operatorname{lnDPS}_{\mathrm{t}}$ and $\operatorname{lnEPS}_{\mathrm{t}}$ exhibit a long term equilibrium relationship defined by $\operatorname{lnDPS}_{t}=a+\beta \operatorname{lnEPS} S_{t}+\varepsilon_{t}$, and $\varepsilon_{t}$ is the equilibrium error, which represents short term deviations from the long-term relationship. $\beta$, cointegrating vector is regarded as an underlying force to make $\operatorname{lnDPS}_{\mathrm{t}}$ and $\operatorname{lnEPS}_{\mathrm{t}}$ to maintain a long term equilibrium relationship. In this study, Johansen (1988) cointegration test 
is used to identify cointegrating relationship among the variables. Johansen (1988) proposed two tests statistics to determine the cointegration rank, which are trace statistic and maximum eigenvalue statistic. ${ }^{3}$

\section{DATA}

\section{Sample Selection And Data Collection}

We select a sample of firms listed on the Korea Stock Exchange over the 26-year period from 1981 to 2006. The following sample selection criteria were employed:

(i) Firms had to have at least 15 years of earnings and dividend data during the period 1980-2006, as reported in the Korea Listed Companies Association database.

(ii) When estimating Eq. (1), all firms with non-positive EPS or zero dividends were eliminated from the sample, in order to prevent the spurious results of dividend smoothing. 4

(iii) A further screen excluded firms with less than 15 observations for each firm characteristic variable used in the regression. From a total of 732 firms, 226 firms fulfilled these screening criteria.

Table 1 shows the descriptive statistics. From this table, the following remarks are found:

<Table 1> Sample Statistics

\begin{tabular}{|c|c|c|c|c|}
\hline Variable* & $\begin{array}{c}\text { Mean } \\
(\mathbf{n = 2 2 6})\end{array}$ & Standard Deviation & Min & Max \\
\hline DE & 0.4081 & 0.2228 & 0.0893 & 1.7382 \\
\hline SEPS & 2424.0 & 2187.5 & 217.5 & 19656.2 \\
\hline SDPS & 354.5578 & 262.2872 & 97.6155 & 2067.0100 \\
\hline EPS & 2260.3300 & 1544.5800 & 268.6437 & 8507.9900 \\
\hline DPS & 468.9158 & 223.8762 & 89.0771 & 1606.9200 \\
\hline LOGD & 5.6286 & 0.5531 & 3.8466 & 7.0639 \\
\hline LOGE & 6.9426 & 0.6145 & 4.9195 & 8.4472 \\
\hline
\end{tabular}

* Dividend payout ratio (DE) is measured by dividends per share divided by earnings per share. Earnings variability (SEPS) is measured using the standard deviation of earnings per share over a minimum of 15 years prior to 2006 and a maximum of the twenty-six years. Dividends variability (SDPS) is measured using the standard deviation of dividends per share over a minimum of 15 years prior to 2006 and a maximum of the twenty-six years. DPS is dividends per share and EPS is earnings per share. LOGD and LOGE stand for natural logs dividends and earnings, respectively.

With regard to average dividend payments, Korean firms paid $468 \mathrm{KRW}$ (or $0.40 \mathrm{USD}$ ) per share. The average dividend payout ratio is $40.8 \%$, which is lower than that of US firms. ${ }^{5}$ The lower observed payout ratio in Korea may be attributable to the different tax treatment of dividend income tax relative to the capital gains tax. Korean firms appear to have less incentive to pay dividends, as the unfavorable tax treatment of dividend income over

3 In this paper, we employed both tests and found that there is no difference between the trace and the maximum eigenvalue tests in detecting cointegrating relationship. The presented result in this paper is based on the maximum eigenvalue test. Before running the cointegration test, stationary tests of the underlying variables are performed by using Augmented Dickey-Fuller (ADF) test. We found both natural log of dividends and earnings are non-stationary at the individual firm level.

4 The exclusion of firms with negative earnings and zero dividends has the advantage of eliminating "spurious dividend smoothing." This spurious dividend smoothing arises naturally, rather than being the result of the conscious management of dividend policy. Dividend smoothing implies a deliberate effort on the part of managers to adjust dividend payments in response to variations in the earnings stream.

5 Average dividend payout ratio from 1930 's to $2000 \mathrm{~s}$ is $54.3 \%$ for S\&P 500 companies. (http://www.barra.com/Research/Fundamentals.aspx) 
capital gain is more serious than is the case in the US. ${ }^{6}$ In addition, many investors in Korea disregard dividends and consider stock price appreciation as the principal component of stock returns. Korean investor's attitude toward dividends may also contribute to lower dividend payout ratios. Dividends variability (SDPS) is 354.55 while earnings variability (SEPS) is 2260.33. Earnings variability is approximately 7 times higher than dividends variability, implying the presence of dividend smoothing.

\section{EMPIRICAL RESULTS}

To test whether earnings and dividends are cointegrated, we run equation (5). For cointegration test, 166 firms $(73.5 \%$ of the total sample) fail to reject the null hypothesis of no cointegration while 60 firms (26.5\% of the total sample) reject the null, concluding cointegration. Summary statistics for equation (5) cointegrating firms are provided in Table 2. Average values for $\beta$ and R-squared for cointegrating firms are 0.258 and $61.11 \%$, respectively.

<Table 2> Summary Statistics for Equation (5)

\begin{tabular}{|c|c|c|c|c|}
\hline Variable* & $\begin{array}{c}\text { Mean } \\
(\mathbf{n = 6 0})\end{array}$ & Standard Deviation & Min & Max \\
\hline$\square$ & 0.6258 & 0.0 .1832 & 0.1485 & 0.9367 \\
\hline R-squared & 0.6111 & 0.2415 & 0.01172 & 0.9452 \\
\hline
\end{tabular}

$* \beta$ is the coefficient of $\ln (\mathrm{EPS})$ in equation (5). 1- $\beta$ measures degree of dividend smoothing. R-squared is the explanatory power of the model.

The dividend signaling hypothesis suggests that there will be a long-term equilibrium relationship between dividend changes and earning changes. Therefore, if there is a deviation from the contemporaneous relationship between earning and dividends, there will be an underlying force to make them to return to the equilibrium relationship. According to the dividend smoothing hypothesis, this underlying force will be a dividend smoothing. This line of reasoning suggests that cointegrating vector in equation (5) should be less than one if earnings and dividends are cointegrated. Table 2 shows that the average magnitude of the coefficient estimator, $\beta$, is 0.6258 , indicating that the degree of dividend smoothing plays an important role to induce firms to maintain a systematic dividend payout policy. . Average explanatory power of the model is $61.11 \%$. It indicates that dividend movements are reasonably well represented by earnings movements. ${ }^{7}$ The results of Table 2 support the dividend smoothing hypothesis.

We further investigate to explain the cross-sectional properties of cointegrating firms and noncointegrating firms implied by the dividend signaling hypothesis. The dividend signaling hypothesis suggests that the higher degree of information asymmetry is more likely to induce firms to maintain a long-term equilibrium relationship between dividends and earnings. To describe a firm's informational environments, we use listing years and firm size as proxies for the information environment. A firm with an older history on an organized stock exchange is expected to generate more public information for the general market investor. Thus, the problem of information asymmetry will be less serious for a firm with a longer listing year. Size can also be used as a proxy for a firm's informational environments. Freeman (1987) and Kross and Schroeder (1988) reported that the market prices of large firms reflected earnings more accurately than those of small firms. Thus, it is possible that smaller firms may have a greater proclivity to use dividends as a signal of value. In fact, Eddy and Seifert (1988) reported that the information content of a dividend change was greater for smaller firms than for large firms. All of these considerations imply that size is likely to reduce signaling needs of dividends. Firm size (SIZE) is estimated by the natural logarithm of average total assets, and listing years (HISTORY) is measured by the number of years listed during the sample period. Table 3 reports the result of the T-test for the difference in group means between cointegrating firms and noncointegrating firms. The T-test for mean differences shows that HISTORY and SIZE of cointegrating firms are significantly less than those of noncointegrating firms. This result seems to indicate that less-known firms have more

\footnotetext{
6 There is no capital gain tax on listed stocks in Korea while $16.5 \%$ of tax is applied to the dividend income.

7 Regression results for noncointegrating firms are not reported since the regression is "spurious regression" if earnings and dividends are not cointegrated.
} 
motivation to have earnings and dividends cointegrated than well-known firms, supporting the dividend signaling hypothesis.

<Table 3> Mean Differences of Informative Variables Between Cointegrating firms and Noncointegrating Firms

\begin{tabular}{|c|c|c|c|c|c|}
\hline & \multicolumn{2}{|c|}{ Cointegrating Firms } & \multicolumn{2}{c|}{ Noncointegrating Firms } & $\begin{array}{c}\text { T-statistics for Mean } \\
\text { Differences }\end{array}$ \\
\hline Variable & Mean & Std.Dev. & Mean & Std.Dev. & \\
\hline SIZE & 18.4331 & 0.8799 & 19.0063 & 1.1919 & $-3.4(\mathrm{P}-\mathrm{value}=0.0008)^{* * *}$ \\
\hline HISTORY & 19.1667 & 2.8946 & 20.8072 & 3.1487 & $-3.5(\mathrm{P}-\mathrm{value}=0.0003)^{* * * *}$ \\
\hline
\end{tabular}

* Significant at the $10 \%$ level. **Significant at the $5 \%$ level. *** Significant at the $1 \%$ level. Firm size (SIZE) is estimated by the natural logarithm of average total assets during the sample period. Listing years (HISTORY) is measured by the number of years listed during the sample period.

\section{Logistic Regression Result}

We test the relationship between the information environment and the firm's dividend payout policy using the logistic regression analysis. Based on the dividend signaling hypothesis, cointegrating firms are hypothesized to face a greater degree of information asymmetry than noncointegrating firms. I assign one to the cointegrating firms, and zero to noncointegrating firms. The logistic estimation procedure is then a maximum likelihood estimate of the probability of being the cointegrating firms conditioned on the informative variables. The result is reported in Table 4. SIZE and HISTORY have a significantly negative relationship with the probability of being cointegrating firms. The result implies that younger and smaller firms have a tendency to have a cointegrating relationship between earnings and dividends.

<Table 4> Result of Logistic Regression by Using Informative Variables as Independent Variables

\begin{tabular}{|c|c|c|}
\hline \multicolumn{2}{|c|}{ Dependent Variable ; Transformed Probability of Being Cointegrating firm } \\
\hline Explanatory Variable & Coefficient & Chi-square \\
\hline Intercept & 10.6711 & $10.9376^{* * *}$ \\
\hline SIZE & -0.4628 & $7.3114^{* * *}$ \\
\hline HITORY & -0.1523 & $7.7032^{* * *}$ \\
\hline Chi-square $=20.90^{* * *}$ & & \\
\hline
\end{tabular}

* Significant at the $10 \%$ level. ** Significant at the 5\% level. *** Significant at the 1\% level. Firm size (SIZE) is estimated by the natural logarithm of average total assets during the sample period. Listing years (HISTORY) is measured by the number of years listed during the sample period.

\section{Robustness Check -Other Considerations}

We check the robustness of the results shown in Table4 by considering other important firm characteristic variables which are known to influence the firm's dividend payout policy. For instance, signaling theory implies that firms with growth opportunities are more likely to pay dividends to convey this information to the market. At the same time, these firms will also have a greater need to retain a higher proportion of earnings to support their valuable investment projects. An implication of this combination of requirements is that high growth firms are likely to be more sensitive to the tradeoff between dividend signaling needs and dividend signaling costs, whereas low growth firms will be much less sensitive to the tradeoff because they would not wish to use costly signals. Ownership structure can also influences dividend policy (i.e., Gomes (2000) and La Porta et al. (2000)). For closely held firms, the immediate change in fundamental value is less visible and, thus, potentially less important for the dividend decision-making process. In fact, Brav et al. (2005) reported that closely held firms regarded the consequences of dividend cuts and omissions to be less serious. They demonstrated that closely held firms were more likely to pay dividends in response to temporary changes in earnings than were firms with diffused ownership. Financial slack can also be considered to be a potentially important factor in dividend payout decision. The presence of financial slack will, in theory, reduce external financing requirements and thus solve the "underinvestment" problem, thereby reducing the signaling needs of firms (i.e., Myers and Majluf (1984) and John and Williams 
(1985)). The effect of leverage on dividend payments is also well known. Higgins (1972) and McCabe (1979) suggested that new long-term debt has a negative influence on the amount of dividends paid. Rozeff (1982) reports that firms with higher financial leverage pay lower dividends in order to avoid the costs of external finance. Finally, the results from earnings volatilities studies have emphasized the relationship between risk and the incentive to pay stable dividends, as high earning volatilities have been shown to be associated with lower than expected future profitability and future stock returns ( Chaney and Lewis (1995). To consider the potential effect of these important determinants of dividend policy, we extend the logistic regression analysis employed in Table 5 by including firm's risk, ownership structure, leverage, growth and slack as control variables. The result is shown Table 5. The results show that information variables have expected signs while the other control variables except risk have insignificant coefficients. Risk (SEPS) has a significantly positive sign implying that firms with a higher risk is more likely to maintain a cointegrating relationship between dividends and earnings. Overall results support the dividend signaling hypothesis.

<Table 5> Result of Logistic Regression by including control variables

\begin{tabular}{|c|c|c|c|c|}
\hline \multicolumn{5}{|c|}{ Dependent Variable ; Transformed Probability of Being cointegrating firm } \\
\hline Explanatory Variable & Estimate & Error & Chi-Square & Pr \\
\hline Intercept & 11.131 & 4.1136 & 7.322 & $0.0068^{* * *}$ \\
\hline SIZE & -0.4863 & 0.2313 & 4.4195 & $0.0355^{* *}$ \\
\hline HISTORY & -0.1562 & 0.0589 & 7.0407 & $0.008^{* * *}$ \\
\hline SLACK & -4.0825 & 2.3871 & 2.9249 & 0.0872 \\
\hline GROWTH & -1.2242 & 2.1679 & 0.3189 & 0.5723 \\
\hline LEV & -0.1817 & 0.2222 & 0.6686 & 0.4135 \\
\hline SEPS & 0.2363 & 0.0911 & 6.7234 & $0.0095^{* * *}$ \\
\hline LARGE & 0.0234 & 0.0158 & 2.189 & 0.139 \\
\hline Chi-square $=31.87 * * *$ & \multicolumn{3}{c}{} \\
\hline
\end{tabular}

* Significant at the $10 \%$ level. ** Significant at the 5\% level. *** Significant at the $1 \%$ level.

Firm size (SIZE) is estimated by the natural logarithm of total assets, growth rate (GROWTH) is the average growth rate of size over a minimum of 15 years prior to 2006 and a maximum of the twenty six years, financial slack (SLACK) is the ratio of accumulated retained earnings to total assets, and earnings variability (SEPS) is measured using the standard deviation of earnings per share over a minimum of 15 years prior to 2006 and a maximum of the twenty-six years. Listing years (HISTORY) is measured by the number of years listed during the sample period. The percentage of the stock held by the largest shareholders (LARGE) is used as a proxy for the concentration of controlling shareholders. Leverage ratio (LEV) is measure by the mean leverage ratio (total liabilities divided by total assets) for a minimum of 15 years prior to 2006 .

\section{CONCLUSIONS}

There have been no empirical attempts to estimate and verify the dividend-earnings relation reflecting both the signaling and dividend smoothing hypotheses. This study proposed a cointegration model to test both hypotheses in an integrated framework in order to provide better insight into the dividend and earning relation. Specifically, this study pursued the following two objectives:

(1) What is the characterization of the optimal dividend payout patterns on the individual firm basis;

(2) What is the effect of information on the firm's dividend payout policy.

The implications of the signaling model and smoothing model of dividends were empirically tested using the recent 26 annual series data of dividends and earnings up to year 2006 for 226 firms. The firms with long-term equilibrium relationship between earnings and dividends are identified through a cointegration test and cross-sectional properties of these firms are investigated. The results show that the presence of cointegration is positively related to the degree of information asymmetry, a result consistent with the dividend signaling hypothesis. In addition, dividend smoothing is identified as an underlying force to make dividends and earnings cointegrated. To ensure the robustness of the empirical results, several firm characteristic variables are added in the logistic regression analysis. The results are virtually unchanged. 


\section{AUTHOR INFORMATION}

Jinho Jeong is Professor of Finance at Korea University. He has been Policy Adviser to Free Economic Zone Authority in Korea, Director of Korea Finance Association, Director of Korea Industrial Economics Association, and Associate Editor of Journal of Korean Finance Study. Professor Jeong received his Ph.D. from Georgia State University (1991). He has taught at University of Otago and Kyungnam University. His research interests and publications are in the areas of dividend policy, financing behavior, market integration, and market efficiency. Professor Jeong has published more than fifty articles in finance journals.

\section{REFERENCES}

1. Brav, A., J.R. Graham, C.R. Harvey and R. Michaely (2005), Payout policy in the 21st century”, Journal of Financial Economics, 77 pp.483-527.

2. Chaney, P.K. and C.M. Lewis (1995), Earnings management and firm valuation under asymmetric information. Journal of Corporate Finance, 1, 319-345.

3. Eddy, A. and B. Seifert (1998), Firm size and dividend announcements. Journal of Financial Research, 11, 295-302.

4. $\quad$ Engle, R.F. and C.W.J. Granger (1987), Cointegration and error correction: Representation, estimation and testing. Econometrica, 55, 251-276.

5. Freeman, R. (1987), The association between accounting earnings and security returns for large and small firms. Journal of Accounting and Economics, 9, 195-228.

6. Gomes, A. (2000), Going public without governance: Managerial reputation effect, Journal of Finance, 55(2), 615-646, 04.

7. Higgins, R. C. (1972), The corporate dividend-saving decision, Journal of Financial and Quantitative Analysis, 7, 1527-1541.

8. Johansen, S. (1988), Statistical analysis of cointegrating vectors, Journal of Economic Dynamics and Control, Vol. 12, 231-254.

9. John, K. and J. Williams (1985), Dividends, dilution and taxes: A signalling equilibrium. Journal of Finance, 40, 1053-1070.

10. Kross, W. and D.A. Schroeder (1988), Firm prominence and the differential information content of quarterly earnings announcements. Journal of Business, Finance and Accounting, 16, 55-74.

11. La Porta, R., F. Lopez-de-Silanes and A. Shleifer (2000), Corporate ownership around the world, Journal of Finance, 55, 1-33.

12. Lintner, J. H. (1956), Distribution of incomes of corporations among dividends, retained earnings and taxes. American Economic Review, 46, 97-113.

13. McCabe, G.M. (1979), The empirical relationship between investment and financing: a new look. Journal of Financial and Quantitative Analysis, 14, 119-135.

14. Miller, M. and K. Rock (1985), Dividend policy under asymmetric information. Journal of Finance, 40, 1031-1051.

15. Myers, S.C. and N. Majluf (1984), Corporate finance and investment decisions when firms have Information thatinvestors do not have. Journal of Financial Economics, 13, 187-221.

16. Rozeff, M.S. (1982), Growth, beta and agency costs as determinants of dividend payout ratios. Journal of Financial Research, 3, 249-259. 